\title{
TURKEY IN THE EURASIAN AREA
}

\section{Esra HATIPOĞLU*}

\section{INTRODUCTION}

The concurrent developments that took place since 1989 have had a profound effect on Turkey's thinking about its role in the post-cold war period.

It is in this context that Turkey has begun to be discussed as a pole of attraction and stability for the Central Asian republics with which it shares linguistic, cultural, religious and ethnic traditions.

This paper looks first at the development of Turkey's political and social relations with the Central Asian republics and then covers also the economic relations between them by taking into consideration mutual interests. This is followed by a brief explanation about the activities of the countries in the region and in the last part it concludes that both Turkey and the regional countries can only benefit from close relations with these republics, not only economically but also politically through increased stability in the region and that the republics can also derive many advantages from such relations. 


\section{A) POLITICAL AND SOCIAL RELATIONS OF TURKEY WITH EURASIA}

Since the disintegration of Soviet Union, Turkey has been trying to extend its sphere of influence into the power vacuum left by the Soviet Union in the Muslim republics, by promoting its image as a secular Muslim country based on the Western model and as a counter model to Iran which seeks to encourage the Islamic religious revival in the region. The Central Asian leaders have also affirmed that they aspire to Turkish-style democracy and prosperity. Kazakh President Nursultan Nazarbaev said in January 1992 that they wanted to implement a free-market economy, and for this their only model was Turkey. Uzbekistan's President Islam Kerimov has indicated that his country should go forward by the Turkish route and Krygzstan's President Askar Akaev described Turkey as the "Morning Star" showing the Turkic republics the way ahead. Even some conservative leaders, i.e. Muslim imams like, democraticminded Akbar Turadzhonzoda, said that Turkey was the best religious and political example even for Iranian - speaking Tajikistan'. It is, therefore, clear that the Turkish model of a secular and democratic Muslim state is the model that comes closest to the predispositions of the leaders of the Central Asian republics.

Turkey's initial efforts to establish ties with the new republics are reflected in her recognition of the independence of the republics. To be recognized by Turkey was very important for them as they themselves indicated in their post - independence visits to Turkey during which they actively sought such recognition.

The first visit of this kind was that of Turkmen President Niyazov in December 1991, followed by the Uzbek President later in the same month, again, asking for Turkey to recognize the independence of the Central Asian republics. Within the same period Kyrgyzstan's President Akaev also came to Turkey for similar reasons.

Each of the presidents, in assessing the results of their visits to Turkey after returning to their own countries described Turkey as the only model that Central Asian republics should follow, underlining the secular position of Turkey.

Azerbaijan was the first republic recognized by Turkey on November 9, 1991. On December 16, Turkey extended recognition to all ex-Soviet republics and became the first country which recognized the independence of all republics of the former USSR after the establishment of the Slavic Commonwealth on December 8, 1991 between Russia, Belarus and Ukraine ${ }^{2}$.

1 Philip Robins, "Between sentiment and self interest" Middle East Joumal, vol: 47, no: 4, Autumn 93, p. 597.

2 Sabah, Sep 17, 1993. 
After the recognition of the independence of these countries, Turkish Foreign Minister Hikmet Cetin paid his first visit in late February 1992 and he was followed in May by then Prime Minister Demirel.

From the point of view of acceptance by the international community, admission to international organizations was also important for the Central Asian republics. As a result of Turkey's efforts on their behalf to gain membership in international organizations. Kazakhstan, Uzbekistan, Azerbaijan, Kyrgyzstan became members of CSCE in January 1992, UN in March 1992, IMF and World Bank in $1992^{3}$.

Turkey, with its linguistic, ethnic and cultural affinities, is the logical partner of Central Asian republics. Although Turkey does not have sufficient financial capacity for the transformation of the economies of the new republics, in most cases purely economic considerations would not be the main determinants of the national interest. Ethnicity, religion, cultural and historical ties will necessarily have an impact on determining alliances and Central Asian republics who find themselves at the centre of geopolitical rivalries, must decide which policy to adopt towards the regional countries and determine whom they can trust and cooperate with easily.

In this respect both Turkey and the Central Asian republics know that there is no need for another big brother dominating the region both culturally and politically as Russia once did.

There are also relatively inexpensive ways to ease the process of transition in the region which Turkey can use, if it is unrealistic to expect major transfers of foreign aid to Central Asia from Turkey.

There is a need for qualified administrators in every field, especially finance, banking, business and management and Turkey has offered assistance in all these areas. There is also a need for economists and legal specialists to carry out tasks ranging from the preparation of a legal framework for privatization to negotiating with international economic organizations and multinational corporations. Providing access to Turkey's educational institutions and funding exchange programmes has helped to reduce the personnel shortages in some areas and deepen the ties between Turkey and the republics.

By 1993, more than 10000 scholarships were granted to students from these republics through which they learn the Western democratic traditions, free thinking and different economic systems enabling them build new political and economical systems in their own countries. There are other projects for student exchange, supply of books and assistance in revising existing books. 
Turkey is also advocating the adoption of the Turkish form of the Latin alphabet as the most convenient, easy to learn and universal. Iran, on the other hand, is pressing the republics to replace the Cyrillic alphabet with a new form of the Arabic script which uses some Persian words. Apart from Tajikistan, which has adopted the Arabic script the other republics (Azerbaijan, Uzbekistan, Krygzstan, Kazakstan and Turkmenistan), accepted on March 16, 1993 to replace their current script with the Turkish form of Latin alphabet plus three additional letters $(q, x, w)^{4}$.

Turkey also introduced satellite broadcasting to the Central Asian republics, an important step in the creation of language unity and the promotion of cultural and social relations. A new channel created specifically for this purpose - the AVRASIA CHANNEL and began broadcasting in May $1992^{5}$. 


\section{B) ECONOMIC RELATIONS OF TURKEY WITH EURASIA}

The collapse of the centrally controlled Soviet economic structure has left the Central Asian republics with serious economic problems.

So, as a first step, it is important to assess the legacy of the Soviet system as it restricts the options open to the newly established republics and then to consider the various structures for Central Asian republics in regulating their future economic relations.

As far as, their existing economic structures are concerned, the main problems can briefly be expressed as follows;

The main indicator in the analysis of the level of economic development of one country is the structure of its employment. According to this indicator, all the republics of Central Asia are still in the pre-industrial stage of development (Table I). Nearly in all republics, industrial employment accounts for less than $30 \%$ of total employment'.

There is a low level of diversification of production in Central Asia (Table II) where agriculture which is largely mono-cultural, has the dominant position in both output and employment. Cotton production occupies $89.8 \%$ of the agricultural land of Central Asia. There are also no independent industrial complexes within the Central Asian republics; all are technologically connected with establishments in the European part of the Soviet Union especially in Russia?.

6 Michael Bradshaw. The Effects of Soviet Disslution. (Royal Institule of International Affairs, London, 1993), p. 11.

7 These are not the only negative effects of the imposition on the region of cotton mono-culture. There are also serious environmental effects. The center's desire for larger yields each year during the Soviet period which placed prionity on quantity of production rather than quality, required extensive irrigation and chemical input and led to ecological disaster. Diversion of the water of the rivers Syrdarya and Amudarya which are supported by the Aral Sea caused substantial shrinking of this sea.

The environment still remains a problem with serious economic consequences in Central Asia.

Rustam Nazikulov, "The Central Asian republics" in Economic Consequences of Soviet Disintegration ed. by John Williamson (Institute for International Economics; Washington, 1993), p. 432. 
Table I : Sectoral distribution of employment, 1987

\section{SECTORAL DISTRIBUTION OF EMPLOYMENT (1987)}

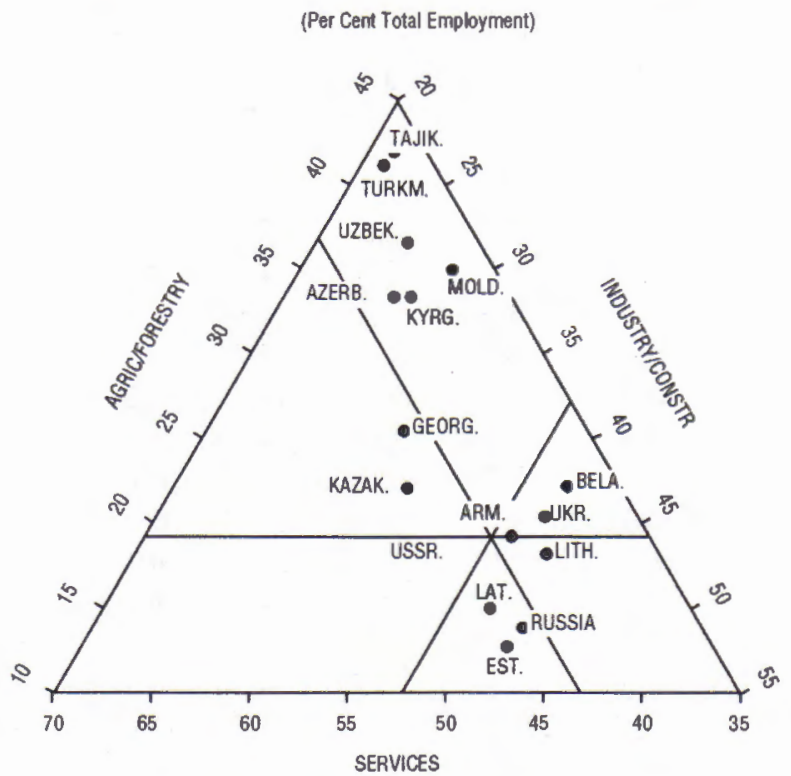

Source: The Economic Effects of Soviet Dissolution. Bradshaw Michael - London 1993, p. 11.

There are also light industry and food processing enterprises in the Central Asian republics which use Russian - speaking labour force since industrial employment is not very popular among workers having local origin because of their weak knowledge of Russian and lack of professional training.

The geographical distribution of oil and gas production in the former Soviet Union is another aspect of dependence of the Central Asian republics on Russia. Since the Russian Federation produces nearly $90 \%$ of the oil (Table III), the other republics continue to depend on Russia for energy supplies. This means that unilateral price increases by Moscow still threaten the security of energy supplies of the republics.

8 Pal Kolsto, "The new Russian diaspora", Journal of Peace Research, vol: 30, no: 2, 1993, p. 200.

9 Michael Bradshaw. The Effects of Soviet Dissolution. (RIIA; London, 1993), p. 16. 
Table II : Republic production of major industrial and agricultural products, 1990

(Percent of USSR Total)

\begin{tabular}{lrrrrrrr}
\hline & 1 & 2 & 3 & 4 & 5 & 6 & 7 \\
\hline Industrial products & & & & & & & \\
Electricty & & & & & & & \\
Oil & 62.7 & 17.3 & 2.3 & 5.1 & 3.6 & 6.0 & 3.0 \\
Gas & 90.4 & 1.0 & 0.4 & 4.5 & 2.2 & 1.5 & - \\
Coal & 78.6 & 3.5 & - & 0.9 & 1.2 & 15.8 & - \\
Iron-ore & 56.2 & 23.5 & - & 18.7 & 0.1 & 1.5 & - \\
Steel & 45.2 & 44.5 & - & 10.1 & 0.2 & - & - \\
Timber & 58.0 & 34.1 & 0.7 & 4.4 & 1.7 & 0.7 & 0.4 \\
Paper & 91.6 & 3.3 & 2.3 & 0.7 & 0.1 & - & 2.0 \\
Machine-Tools & 85.2 & 6.0 & 3.2 & 0.1 & 0.5 & 0.4 & 4.6 \\
TV Sets & 47.2 & 23.6 & 9.8 & 12.6 & 6.9 & 5.2 & 5.7 \\
Refrigerators & 44.8 & 35.8 & 12.3 & - & 1.8 & - & 5.3 \\
Footwear & 58.1 & 13.9 & 11.2 & - & 7.1 & 5.7 & 4.0 \\
Cotton Cloth & 45.7 & 23.3 & 5.5 & 4.3 & 8.8 & 8.8 & 3.6 \\
Woollen Cloth & 71.7 & 7.2 & 1.8 & 1.9 & 4.3 & 9.1 & 4.0 \\
& 66.1 & 10.3 & 6.6 & 4.8 & 3.6 & 2.4 & 6.2 \\
Agricultural products & & & & & & & \\
& & & & & & & \\
Grain & 53.3 & 26.0 & 3.8 & 9.6 & 2.5 & 2.0 & 3.0 \\
Meat & 51.3 & 21.3 & 6.9 & 6.9 & 3.5 & 3.7 & 6.4 \\
Milk & 51.4 & 22.6 & 6.9 & 5.2 & 3.3 & 4.9 & 5.9 \\
Eggs & 58.1 & 20.0 & 4.4 & 5.1 & 4.1 & 5.1 & 3.3 \\
Fish & 74.1 & 10.1 & 0.2 & 0.8 & 2.0 & 0.7 & 12.2 \\
Sugar & 30.2 & 54.4 & 2.8 & 2.6 & 3.8 & 3.0 & 3.2 \\
Butter & 47.9 & 25.5 & 9.2 & 4.9 & 1.9 & 2.2 & 8.4 \\
Oil & 35.5 & 32.8 & 0.8 & 2.9 & 5.8 & 21.8 & 0.4 \\
Cotton & - & - & - & 3.8 & 6.4 & 89.8 & - \\
\hline & & & & & & & \\
\hline
\end{tabular}

Key: 1. Russia, 2. Ukraine, 3. Belarus, 4. Kazakhstan, 5. Trancaucasus and Moldava, 6. Central Asia, 7. Baltic States.

Sources: Goskomstat SSSR, Noradnoe khozyaistvo SSSR v 1990g., Moscow, Finansy i statistika, 1991, pp. 358-361 in The Economic Effects of Soviet Dissolution by Bradshaw Michael, London, 1993, p. 12. 
Table III : Geographical distribution of oil production in the former USSR

(Million metric tons a year)

\begin{tabular}{|c|c|c|c|c|c|c|}
\hline & 1980 & 1985 & 1990 & $\begin{array}{l}1991 \\
\text { Total }\end{array}$ & $\begin{array}{c}1991 \\
\text { Percent }\end{array}$ & $\begin{array}{c}1990-91 \\
\% \text { change }\end{array}$ \\
\hline $\begin{array}{l}\text { Former USSR } \\
\text { (Total) }\end{array}$ & 603.2 & 595.3 & 570.8 & 515.0 & 100.0 & -9.8 \\
\hline Russia & 546.7 & 542.3 & 516.2 & 461.1 & 89.5 & -10.7 \\
\hline Siberia & 315.2 & 370.7 & 377.4 & 330.9 & 64.3 & -12.3 \\
\hline Ukraine & 7.5 & 5.8 & 5.3 & 4.9 & 0.9 & -13.2 \\
\hline Belans & 2.6 & 2.0 & 2.1 & 2.1 & 0.4 & 0.0 \\
\hline Georgia & 3.2 & 0.5 & 0.2 & 0.2 & 0.03 & 0.0 \\
\hline Azerbaijan & 14.7 & 13.1 & 12.5 & 11.7 & 2.3 & -6.4 \\
\hline Kazakhstan & 18.7 & 22.8 & 25.8 & 26.6 & 5.2 & 3.1 \\
\hline Turkmenistan & 8.0 & 6.0 & 5.6 & 5.4 & 12.0 & -3.6 \\
\hline Uzbekistan & 1.3 & 2.0 & 2.8 & 2.8 & 0.5 & 0.0 \\
\hline All others & 0.5 & 0.8 & 0.3 & 0.2 & 0.03 & -33.3 \\
\hline
\end{tabular}

Source: Sagers, M.J. "Review of the Energy Industries in the Former USSR in 1991". Post-Soviet Geography. 1992, vol: 33, no: 4, p. 241 in The Economic Effects of Soviet Dissolution by Bradshaw Michael, London, 1993, p. 16. 


\section{Table IV : Geographical distribution of natural gas production} in the former USSR

(Billion cubic metres a year)

$\begin{array}{cccccc}\text { 1980 } & 1985 & 1990 & \begin{array}{c}1991 \\ \text { Total }\end{array} & \begin{array}{c}1991 \\ \text { Percent }\end{array} & \begin{array}{c}1990-91 \\ \% \text { change }\end{array}\end{array}$

\begin{tabular}{lrrrrrr}
$\begin{array}{l}\text { Former USSR } \\
\text { (Total) }\end{array}$ & 435.2 & 642.9 & 814.8 & 810.5 & 100 & -0.5 \\
Russia & 254.0 & 462.0 & 640.6 & 642.9 & 79.3 & 0.4 \\
Siberia & 161.7 & 382.8 & 577.8 & 582.4 & 71.9 & 0.8 \\
Ukraine & 56.7 & 42.9 & 28.1 & 24.4 & 3.0 & -13.2 \\
Azerbaijan & 14.0 & 14.1 & 9.9 & 8.6 & 1.1 & -13.1 \\
Kazakhstan & 4.3 & 5.5 & 7.1 & 7.9 & 1.0 & 11.3 \\
Turkmenistan & 70.5 & 83.2 & 87.8 & 84.3 & 10.4 & -3.9 \\
Uzbekistan & 34.8 & 34.6 & 40.8 & 41.9 & 5.2 & 2.7 \\
All others & 0.9 & 0.6 & 0.5 & 0.5 & 0.06 & 0.0 \\
\hline
\end{tabular}

Source: Sagers, M.J. "Review of the Energy Industries in the Former USSR in 1991". Post-Soviet Geography. 1992, vol: 33, no: 4, p. 253 in The Economic Effects of Soviet Dissolution by Bradshaw Michael, London, 1993, p. 16. 
Table V:

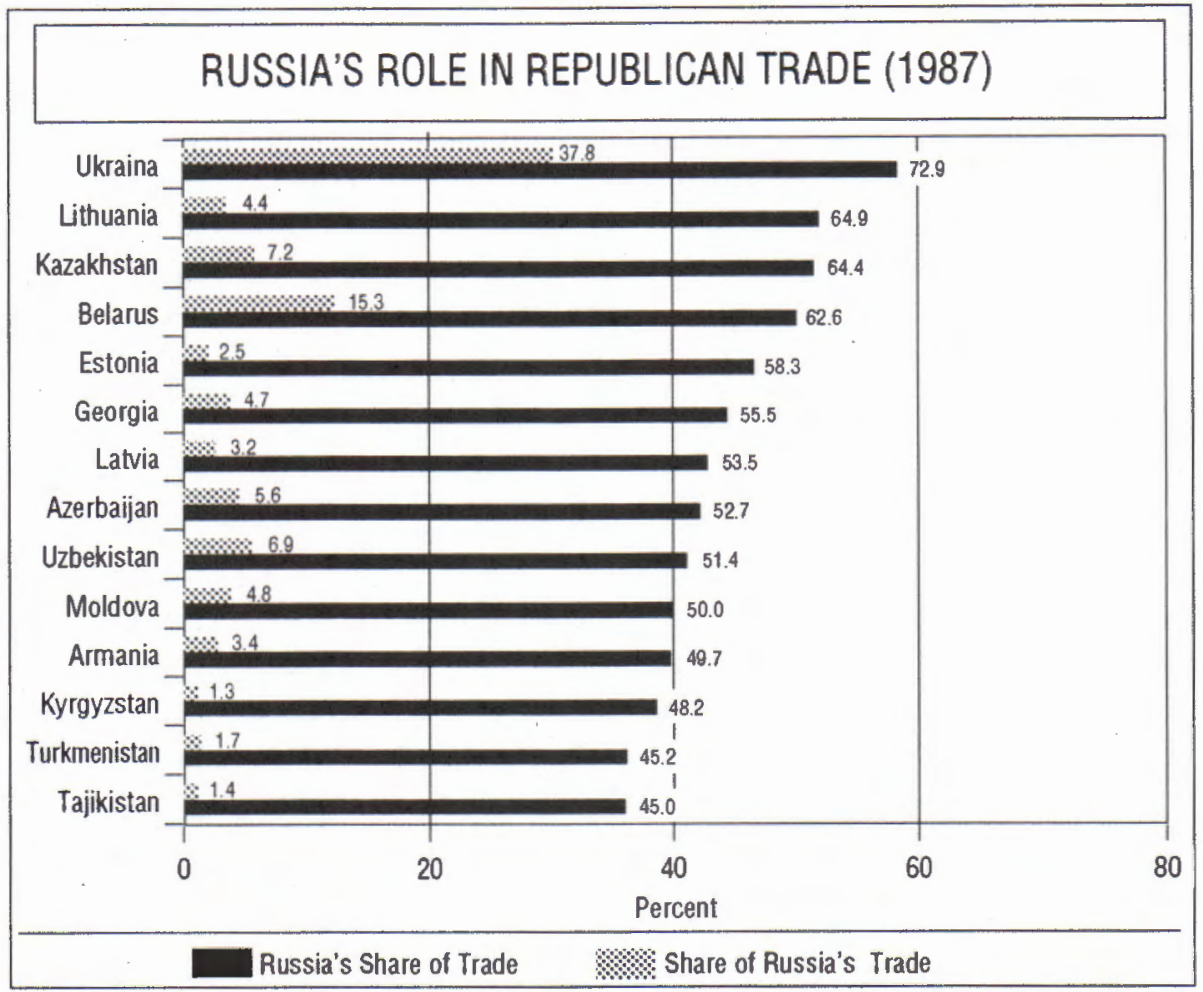

Although there are some significant sources in Central Asia, Russian Federation is also the most important producer of natural gas (Table IV).

Growing transfers from the state budget of the Soviet Union also led to an increased transfer dependence in the Central Asian republics. The most important economic question for the Central Asian republics, after disintegration, is how to resolve the budget deficits which were previously financed with transfers from the state budget ${ }^{10}$.

Table V illustrates the role of Russia in inter republic trade and dependence of the republics on trade with Russia.

Central Asian republics' participation in the ruble zone was another key factor explaining dependence on Russia.

10 Rustam Narzikulov, "The Central Asian Republics" in Economic Consequences of Soviet Disintegration ed. by John Williamson (Institute for International Economics, Washington, 1993), p. 435. 
The desire to assert economic independence and state identity, the desire to get rid of uncontrolled financing of public deficits and high inflation have urged the republics to introduce their own currencies. Within this context, Kyrgyzstan's President Askar Akaev cancelled all dealing in US \$ or rubles on 10 May 1993 and introduced the som as its own national currency". Turkmenistan left the ruble zone on November 1, 1993 and introduced its own national currency known as the manat. Kazakhstan's President Nazarbaev has expressed his desire to leave the ruble zone and introduce the tanga as republican currency ${ }^{12}$. Uzbekistan is also preparing to introduce its own currency, the soum - now both the ruble and the soum can be used ${ }^{13}$.

What then can Central Asian republics do to overcome this dependence on Russia?

There are three complementary options for Central Asian republics;

1) To remain within the CIS integration process in order to reduce damage to the trade-sensitive Central Asian economies. Since in all Central Asian republics, the progress of re-orientation is limited by a lack of capital for investment (shortage of capital needed to fund economic restructuring), they must also compete with one another as well as with the countries of Central and Eastern Europe for Western assistance. It is also unrealistic to suppose that inter republic trade can simply switch to trade in convertible currencies at world prices (lack of sufficient currency in CIS).

Given these difficulties, it is important for the republics, in the short run, to remain within the CIS economic structure in order to stabilize the challenge of reforging the economic links that bind them to the remaining ex-Soviet republics. Since attempts to replace the existing inter republic trade pattern with the trade links to neighbouring countries or the West could create some difficulties with the existing institutional structures of new republics, this inter republic trade must continue in the transition period on a different path which could help the republics in their integration process to the world economy and in their transformation process toward a system based on market economy ${ }^{14}$.

Remaining within the CIS integration process would require the Central Asian republics to balance the economic benefits of integration against the political costs of Russian dominance.

11 Far Eastern Economic Review, May 1993.

12 Sabah, September 7, 1993.

13 Sabah, November 15, 1993.

14 Martha Brill Olcott, "Russia's place in the CIS", Current History, vol: 92, no: 576, October 1993, pp. 314-317. 
2) To establish a Central Asian Commonwealth. The leaders of Central Asian republics held summits in an attempt to set up mechanisms for regional cooperation, at least, on some economic issues.

The first, initiated by Kazakhstan, was held in Alma-Ata in June 1990. Leaders stated their intention to coordinate their political, economic and cultural policies. During the second, held in August 1991, they tried to give, substance to their earlier statement. They decided to create a coordinating Council to deal with economic issues but the Council could not be created due to the Moscow coup attempt. In the meantime some of the republics declared their independence ${ }^{15}$. The next summit among the Central Asian republics was held in December 1991 where their leaders discussed ways of dealing with the disintegration of the USSR. They decided to demand membership in the already created Slavic Commonwealth of Russia, Belarus and Ukraine instead of creating a rival Central Asian Commonwealth.

After deciding to join $\mathrm{CIS}$, the leaders of the Central Asian republics met again in April 1992 in Bishkek to organize mechanisms for regional cooperation, but no sperific steps were taken.

At the next summit, held in January 1993 in Tashkent, presidents of the Central Asian republics adopted programme including one which provided for refining of some of Kazakhstan's oil in Uzbekistan and Turkmenistan and the creation of four committees of experts in various regional capitals. The committee on energy is to be located in Bishkek, the committee on oil in Ashkhabad, on cotton in Tashkent and on grain in Alma-Ata. They also agreed to give humanitarian aid to Tajikistan, to create a common information area covering the whole of Central Asia, using the Tashkent Television and Radio Centre as a base and a regional newspaper to be published in Alma-Ata. This summit was regarded by some commentators as a stage in the dissolution of CIS and Central Asian republics, therefore, had to declare that they had no intention of leaving the CIS.

The most recent of such attempts was of that the creation of an economic union between Uzbekistan and Kazakhstan which, if implemented, would result in free movement of capital, labour, services and goods between Uzbekistan and Kazakhstan ensuring the removal of tariffs and customs duties ${ }^{16}$.

$\begin{array}{lll}\begin{array}{l}\text { Declaration of; } \\ \text { Name of } \\ \text { republic }\end{array} & \text { sovereignty } & \text { independence } \\ \text { Uzbekistan } & \text { June } 20,90 & \text { August } 31,91 \\ \text { Turkmenistan } & \text { August } 22,90 & \text { October } 27,91 \\ \text { Kyrghyzstan } & \text { Dec. 12 }, 90 & \text { August } 31,91 \\ \text { Azerbaijan } & \text { Sept. } 23,89 & \text { August } 30,91\end{array}$


It must, however, always be kept in mind that such links among the Central Asian republics would not provide them with the necessary capital and technology which the Western countries could bring, but would help the republics to realize gains from trade and to rationalize their economies. This integration process could only be achieved through initial investment for establishing new storage, processing and distribution systems since the existing infrastructure has initially linked with Russia.

3) To be part of a larger regional arrangement composed of neighbouring countries, i.e. ECO and the Black Sea Economic Cooperation Organization.

ECO (Economic Cooperation Organization) is an organization originally established by Turkey, Iran and Pakistan in 1985. In the last few years, the group has been expanded to include Afganistan and the Caucasian republic of Azerbaijan as well as the five Central Asian republics of Kazakhstan, Kyrgyzstan, Uzbekistan, Tajikistan and Turkmenistan. It now represents, both geographically and demographically, the largest economic bloc after the European Union.

At the first summit of the organization, the foreign and economic ministers of member states issued the Quetta ${ }^{17}$ Plan of Action for ECO. The plan included provisions for setting up road, rail and air links, the development of ports, the abolishment of visas, tariffs, customs duties and other restrictions on the free movement of people and goods ${ }^{18}$.

The second ECO summit, which took place in Istanbul, on June 5 1993, the member states agreed to set up road, rail and telecommunication links, to establish the ECO Trade and Development Bank, a common market like the EU, to abolish double taxation and visas, to ensure proper use of energy resources of member states, to establish relations with some of the international organizations for environmental purposes and also agreed to contribute equally to the ECO Fund established for the reconstruction of the Development Bank.

If all these decisions are implemented, all member Central Asian states which seek alternative markets, will benefit ${ }^{19}$.

Another regional organization, which was created with the initiative of Turkey in February 1992 - the Black Sea Economic Cooperation Organization, includes the Black Sea coastal states (Turkey, Romania, Bulgaria, Moldavia, Russia, Ukraine and Georgia). Turkey also invited other states in the region to join in the hope of creating an atmosphere of closer cooperation and friendship. Thus, countries like Greece, Azerbaijan and Albania became members and signed the Summit Declaration on 
June 25, 1992, in Istanbul. On August 31, the Turkish business community invited Co-chairmen of all the business councils founded in these countries to Istanbul to evaluate the existing potential in these countries ${ }^{20}$.

BSEC aimes at economic cooperation and free circulation of goods, services and capital between member states. It also tries to encourage Free Economic Zones to attract direct foreign investment and capital into the region. The project tries to assure support for small and medium - size enterprises, abolish double taxation and visas, compel member states to cooperate in other issues such as environment, transportation and energy.

For the new republics which need to reorient their economies through new sup-. plier networks, regional markets, commodity exchanges, the creation of new private enterprises, joint ventures, together with these regional organizations, bilateral economic and trade links with regional countries like Turkey, Iran, Israel, Pakistan, are also important.

4) Another option for the new republics is to establish closer cooperation with regional countries which could provide them the required foreign investment for the development of processing facilities for their raw materials.

\section{Table VI : Options for Central Asian republics in regulating external relations}

CIS

Integration

Central Asian

Commonwealth

Regional

Organizations

Bilateral

Relations

$$
\begin{aligned}
& \text { Interepublican + } \\
& \text { Relations }
\end{aligned}
$$

Relations among

Central Asian Republics

ECO

Black Sea Economic Organization

Caspian Sea Organization

Turkey

Iran

China

Pakistan

Israel 
Iran is one of the regional country which wants to enhance its influence with the Central Asian republics. It offers Central Asian republics both economic and technical assistance and proposes projects in the fields of energy and transportation. As an alternative to the Turkish Black Sea Project, it also offers its port of Bandar Abbas as a commercial outlet to the Central Asian republics for access to Indian Ocean. The other initiative of Iran was the creation of a Caspian Cooperation Council, including the coastal states; Iran, Russia, Kazakhstan, Turkmenistan and Azerbaijan (April 1992). The aim was to allow Iran to use the ports of Kazakhstan and Turkmenistan for exports to East Asia and Kazakhstan and to allow Turkmenistan to use the ports of Iran for exports to Europe and the Middle East.

Apart from these projects, there are also agreements on the revival of the Silk Road through a highway from Turkey to Central Asia and Western China.

Trade between China - the other regional power - and the ex-Soviet republics also increased rapidly from $\$ 1.2$ in 1985 to $\$ 6$ billion in 1991 China has substantial surpluses of consumption goods which are in great demand in the republics, and the republics have raw materials and mining products which are important for China.

Pakistan, Israel, South Korea and Japan are also keen to establish economic relations with the Central Asian republics.

As indicated above, with the collapse of the Soviet Union, Central Asian republics began to search for for trade partners especially with the neighbouring countries such as Turkey, Iran and China. These countries are also keen to establish a presence in Central Asia which could become a basis for their political influence.

Given the divergent interests of these countries it is clear that Central Asia has became an area of foreign competition.

The position of Turkey vis-a vis the Central Asian republics however is different from that of other countries in the region.

When the Central Asian republics began declaring their independence towards the end of 1991, there was a great debate about Turkey's future role in this changing situation. The close historical, linguistic and cultural ties of Turkey with the republics was frequently mentioned and Turkey was shown as an economic and political model for these new republics. There was also much speculation about Turkey's future foreign policy orientation. In those days, Turkey continued to insist on the priority of relations with the West in terms of foreign policy.

As the barriers dividing Turkey from these republics disappeared, however requests from the Central Asian republics brought strong pressure on the Turkish leadership. Initially it was not Turkey's ambition but pressure from these republics which initiated the cooperation process between Turkey and the Central Asian republics. This situation contrasts sharply with the positions of the other countries in the region which are keen to establish economic and political relations with the republics. 
As far as economic relations are concerned, what then, are the projects and activities of Turkey in the region which make her the economic partner of the Central Asian republics?

The Turkish government and the Turkish business community are presently engaged in considerable activity with the former Soviet republics, the main emphasis of which is on trade and investment.

The main activity of Turkish firms operating in Kazakhstan is construction, the primary projects being the construction of hotels, a business center in Alma-Ata, an industrial plant for the production of copper cables in Semipalantinsk and the construction of a gas station complex in Alma-Ata.

The construction of a dairy products factory in Zaisan was completed by a Turkish firm, Cukurova, in 1992. Agreements for the construction of a wood carving factory in Aleksieva and a brick factory in Zaisan region were also signed by the same firm.

A Turkish telecommunication company, NETAS, has set up a joint-venture with Vesnet to produce telecommunications equipment in the Urals.

An agreement was signed with the Turkish construction firm, BIRLEŞMiŞ MÜHENDISLER ODASI, and an American Anglo-Dutch firm for developing the Tenge oil deposits in Mangistau region. Another agreement was signed for the operation of four oil fields, rehabilitation of two other oil fields and the construction of a thermal power plant in Aktubinsk.

TURK PETROL ANONIM ORTAKLIĞI / Pet Holding established a joint-venture with Kazakh National Petroleum Company in November 1992 to operate five oil fields.

In the banking sector, the joint - venture agreement to establish KazakhTurkish Bank (Kazkommerts - Ziraat International Bank) was signed between T.C. ZiRAAT BANKASI and the Kazakh Kazkommertsbank ${ }^{21}$.

In Uzbekistan, a Turkish textile manufacturing firm is developing a project for the establishment of a thread dyeing, weaving and manufacturing factory. Another Turkish textile company established a joint-venture in Fergana for producing goods, using local materials and machinery supplied by Turkey.

In the construction sector, projects undertaken by Turkish firms include the construction of two hotels and a cement factory.

In the food industry, a Turkish-Uzbek joint-venture was established for processing dried food.

In the banking sector, the joint - venture agreement to establish Uzbekistan Turkish Bank was signed between T.C. ZIRAAT BANKASI and Uzagroindustrial Bank ${ }^{22}$. 
In Kyrgyzstan, Turkish firms are mainly interested in construction, mining, consumer goods, oil and gas exploration and telecommunication projects. NETAS, a Turkish firm, is in the process of establishing a roadrolink system in the city of Tokmak and is also interested in modernisation of the telecommunication system of Bishkek.

There are also many joint-ventures between Turkish and Kyrgyz firms including the construction of a pipe factory, a fur processing factory, a sugar plant, a five star hotel, a shoe factory, a mobile crude oil refinery with 6000 barrals per day capacity, etc ${ }^{23}$.

In Azerbaijan, Turkish investment is mainly concentrated in the construction, telecommunications, manufacturing and energy sectors. Pending projects includes the Baku Water Project, undertaken by three Turkish firms, the South Mugan Irrigation Project and the restoration of the Old Moscow Hotel.

In July 1992, Turkey's PTT signed an agreement of cooperation with the Azerbaijan Ministry of Communication.

A Turkish -Azeri joint- venture has been established for footwear production, while another Turkish firm, PETEKS, is active in leather processing and clothing production.

In the energy sector, construction of a petro chemical plant is being carried out by a Turkish company, ÇBS BOYA. A 50/50 joint - venture with an Azeri firm for oil and gas exploration has been established and agreements have been signed for oil transport from Azerbaijan to Europe through Turkey.

In 1992, Telecom and NETAS connected DMS switches designed by themselves in Azerbaijann ${ }^{24}$, while a contract for the expansion of the Ashkahabad airport was signed in October 1992 by John Laing and the Turkish company ALARKO.

In the banking sector, the joint-venture agreement to establish AzerbaijanTurkish Bank was signed between Agrar Senaye Bank and T.C. ZIRAAT BANKASI.

In Turkmenistan Turkish investments are mainly concentrated in construction.

The construction of a deep-freeze storage facility financed by Eximbank credits and hard currency, as well as a five-star hotel, 150 kilometers of railway, a natural gas pipeline transporting Turkmen gas to Turkey and Europe with 15-20 billion cu.m/ year capacity and an eye surgery centre are important cooperative projects planned for cooperation for Turkmenistan.

Joint-ventures were established for the establishment and rehabilitation of two oil refineries and for the construction of motels and restaurants.

In the banking sector, also in Türkmenistan the joint-venture agreement to establish Turkmen-Turkish Commercial Bank was signed between T.C. ZiRAAT BANKASI and Turkmen Agroprombank ${ }^{25}$. 


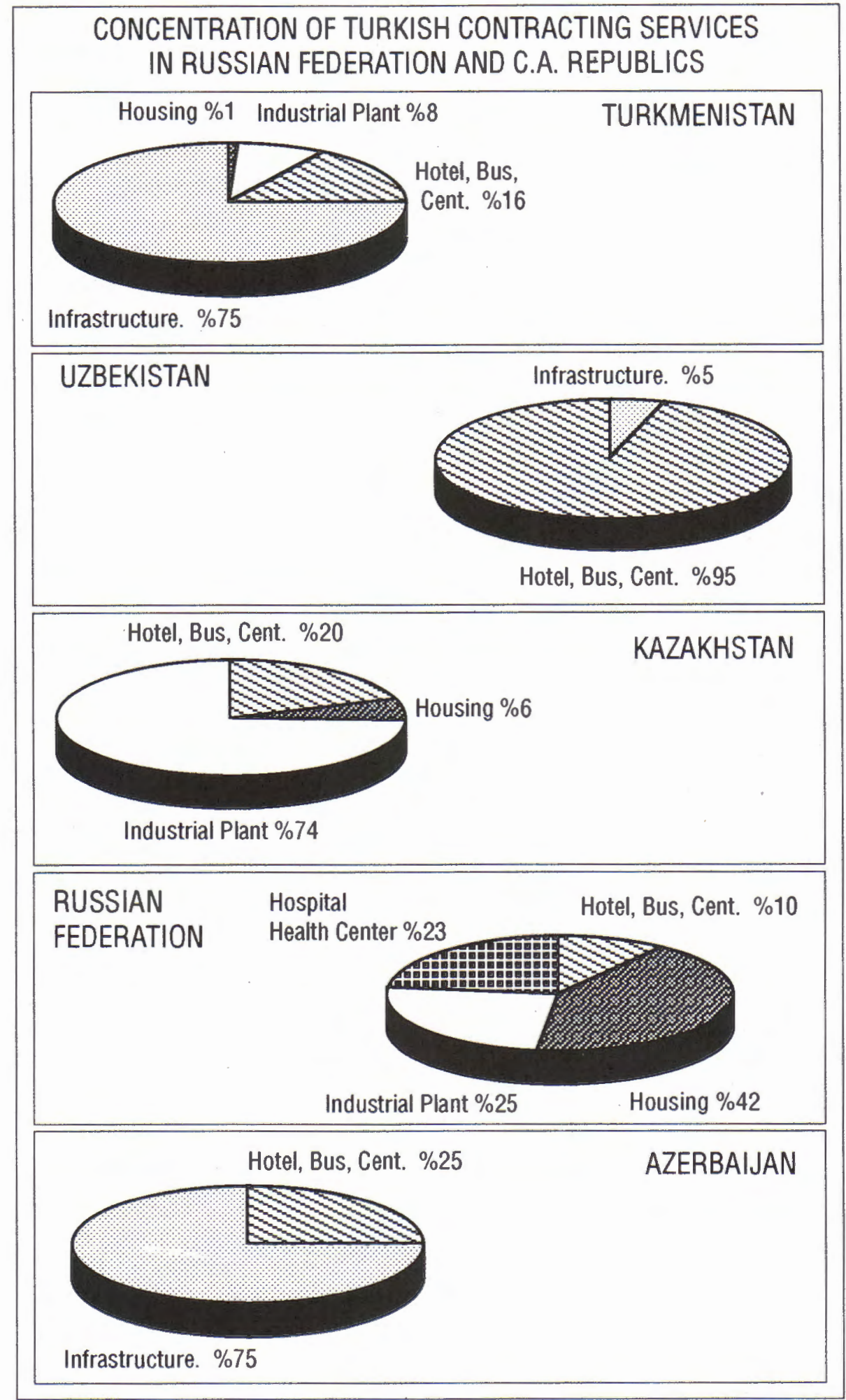

Source: DEIK Bulletin, September 1993, p. 6. 
Table VIII : Turkish aids and credits extended to republics

(million \$)

1991/1992

1993 June

TOTAL

Technical aid

1.40

5.33

6.73

- from TICA

6.75

3.65

10.40

- total

8.13

8.98

17.13

Humanitarian aid

130.00

160.00

310.00

- from TICA

0.00

0.03

0.03

- total

150.00

160.03

310.00

Ministry of Education

15.57

5.31

20.88

(10000 students)

Department of Religious

Affairs

0.00

1.30

2.50

TOTAL AID

170.72

176.32

350.58

Eximbank Credits

177.00

10.00

187.00

Government Credits

285.00

9.00

285.00

TOTAL CREDITS

462.00

10.00

472.00

TOTAL

635.72

186.92

822.63

Source: TICA (International Cooperation Agency) Documents, January 1994. 
Table IX : Decomposition of credits extended to republics

\section{NAME OF \\ REPUBLIC}

Uzbekistan

Kazakhstan

Turkmenistan

Kyrgyzstan

46.3 (project)

28.7 (trade)

$$
\begin{array}{ll}
125 & \text { (project) } \\
125 & \text { (trade) }
\end{array}
$$

150.5 (project)

49.5 (trade)

150 (project)

100 (trade)

15 (project)

75 (trade)
CREDIT

AGREEMENT

Febr 1, 1993

June 5,1992

Dec 13, 1992

Aug 20,1992

Apr 21,1993

Jan 23, 1993

Oct 23,1993

Jan 15,1993

June 20,1993

Source: Eximbank Documents, January 1994. 
To forge immediate ties with the republics, Turkey also announced a series of aid arrangements with the republics in the form of technical aids and Eximbank credits (Tables VIII and IX).

Given the shortage of foreign currency and easily tradeable goods, Turkey has also tried to promote barter arrangements and to make available to corporations wanting to invest in the region, all necessary information and knowledge about the investment conditions, risks, legal procedures and analyses of Central Asia.

Further, the fact that Turkey is not geographically close to the republics has compelled her to find direct transport facilities, since until very recently flying to Baku, Tashkent or Alma-Ata was only possible via Moscow. Turkey therefore became the first country to establish air routes for the republics in May 1992.

The Central Asian republics are still in the process of emerging from under the Russian umbrella. It is still doubtful whether Russia views them as fully independent. Within this context, therefore, most Turkish economic projects and activities aimed at setting up integrated structures for production, processing, packaging, distribution and servicing, in order to decrease the dependence of Central Asian republics on Russia.

Turkey does not however want to create a conflict situation in the region with Russia since Russia is still regarded as an important actor, holding a dominant position in Turkey's inner circle of maneouver. Thus, Turkey's policies have been formulated so as to be compatible with those of Russia in a way to decrease potential friction between them. This approach was affirmed by Prime Minister Tansu Ciller on her visit to Moscow in September 1993 where she said that Turkey and Russia should learn to live together in peaceful coexistance to become partners and not competitors in the region and should try to cooperate in solving problems ${ }^{26}$. As the above statements clearly indicate, the main goal of Turkey's policies vis-a vis the Central Asian states is a smooth conclusion of the differentiation process and avoidance of further distruptions or irregularities within the socio - political and economic orders of the new republics. 


\section{C) THE NEIGHBOURING COUNTRIES: THE POLITICAL INTERESTS}

While the Central Asian states as the socio-political orders, are approaching their state status, together with various internal problems, we must also emphasize the activities of the regional countries.

Within this context, there are two regions which could be designated as important areas of maneouver for Central Asian republics; the inner region, i.e. the neighbouring countries - Russia, Turkey, Iran, Pakistan, Saudi Arabia, China etc. and the outer region - the European Countries and USA.

The Russian Federation, remains the most powerful ex-Soviet republic, comprising 60 percent of the population and 76 percent of the territory of the former Soviet Union.

Although it is passing through deep economic crisis with its huge budget deficit, high inflation rate, decline in production level etc., it remains one of the world's greatest powers due to its size, resources, political and psychological inheritance ${ }^{27}$.

As indicated above, the disintegration of the USSR, although rousing many republics to independence, did not eliminate dependence on Russia. There remain many indications of this relationship. Today, nearly all the republics, the most recent example being Azerbaijan, are ruled by the old Soviet officials who later became nationalist figures. The professional personnel in the region are also often of Russian origin. After the dissolution of the Soviet Union, Russian migration from the republics caused a significant loss of doctors and other specialists in Central Asian republics ${ }^{28}$.

As far as military capacity is concerned, the degree of dependence is still high because the Central Asian republics' own military capacity is inefficient. Russian forces still constitute the main military force within the territory of the former Soviet Union. Ninety percent of Uzbekistan's military officers are ethnic Russians, six thousand Russian officers supervise the Turkmenistan army, Tajikistan is completely dependent on Russian forces to counter the islamic opposition. The same role is also played by the Russian military in some former Soviet republics i.e. Azerbaijan and Georgia which were initially reluctant to join CIS, arguing that the new organization merely given a new name for the Russian dominated USSR ${ }^{2}$. p.314. 
The first and foremost foreign policy for Russia is characterized by its orientation and relations with the other republics of the former Soviet Union, especially with Ukraine and Kazakhstan. This is both because of the existence of a high proportion of Russian - speaking population in these republics and because of their nuclear status.

As far as nuclear status is concerned, Kazakhstan is home to 104 SS-18 intercontinental ballistic missiles (heavy missiles which are the largest in Soviet strategic forces, each missile carrying 10 555-kiloton warheads) based at Drzhavinsk and Zhangiz - Tobe. The 40 TU-95 bear bombs are deployed at a base near Semipalantinsk. Kazakhstan was the former Soviet Union's primary location for nuclear tests (Semipalantinsk, Caspian Sea etc.) and contained the Baikonur / Tyuratam space facility (heart of the former Soviet Union's space program) and the Sary Shagan site used for testing of antiballistic missiles and air defence systems ${ }^{30}$.

Together with the other newly independent republics Kazakhstan also agreed to renounce the possession of nuclear arms and became one of the four ex-Soviet republics to sign the Lisbon Protocol on 23 May 1992 by which it agreed to destroy or turn over to Russia all strategic nuclear warheads and to accede to the 1968 Nuclear Non-Proliferation Treaty. However, according to Russia the problem of nuclear weapons in Kazakhstan has not yet been solved.

From the above, it can easily be understood that Russia is still very powerful and very much involved in the internal affairs of the ex-Soviet republics especially those in Central Asia and Caucasus and still struggles for leadership in the region by tacitly threatening the dismemberment of those states that wish to leave Moscow's sphere of influence.

Iran is the other country in the region which wants to enhance its power in the newly independent Central Asian republics, but where the question of Iran arises, the discussion of Central Asia's political future inevitably turns to the subject of Islamic fundamentalism.

The Iranian Revolution awakened the West to the revolutionary potential of islam and focuses attention on the Muslims of the Soviet Union. Even before the events of 1989 and 1991 there were specialists who argued that the Soviet Union would disintegrate in the near future due to the growing population of Soviet Muslims whose increasingly militant Islamic identity would lead them to revolt against the Soviet Union ${ }^{31}$. Now, the Soviet Union has disintigrated into independent republics, not

30 John R.W. Lepingwell, "Kazakhstan and nuclear weapons", RFEIRL Research Report, vol: 2, no: 8, February 19, 1993, pp. 21-24.

31 Is leading proponents were Alexandre Benningsen, Chantal Lemercier - Quelquejay, Marie Broxup, Michael Rywkin.

Muriel Atkin, "The Islamic Revolution that overthrew the Soviet State", Contention, vol: 2, no: 2, Winter 1993, pp. 89-91. 
because of the activities of radical Islam but because of the dissolution of the Soviet system itself.

With the disintegration of the Soviet Union's institutional framework and ideology, however, Islam could become a powerful political force in Central Asia and, if this is the case, it is important to state the different models of the development of Islamic states as argued by Alexeyev; these are the Turkish model where the Islamic factor does not play an important role in state affairs although the importance of Islam in the daily life of the citizens continues; the Iranian model where the state is headed by Islamic clergy who impose strict religious rules on the society and the third type of Islamic state where, while Islamic values predominate in society, the fundamentalists still do not have real political and social power, like in Pakistan or Iraq ${ }^{32}$.

Today, the main question, according to Alexeyev, is which type should be adopted by the Central Asian republics as a model in this restructuring period. It is, however, very difficult to provide one model for all the republics since it is hard to ignore the economic, political and cultural variations among the individual republics of Central Asia.

The Islamic fundamentalist movement may occur in one region due to various reasons: a) if there is geographical and ethnic proximity to the state where fundamentalist forces dominate; $b$ ) if the living and educational standards of the population is low or c) if there is internal confusion which is sought to be manipulated by external powers. All these factors operated in Tajikistan and made Tajikistan a test case for fundamentalist activities ${ }^{33}$.

It is hard, however, to find these factors for the remaining republics of Central Asia because first, the great majority of the population, with the exception of Azerbaijan, are Sunnis and this creates a natural barrier between Shia Iran and the republics. Secondly, they have secular educated classes due to Soviet educational and cultural policies who will be alert to the possibility of such attempts at manupulations.

Yet, we must not forget that the challenge posed by Islamic organizations to secular regimes has transnational effects i.e. the Islamic Revival Party's activities touch the whole of $\mathrm{CIS}$ including Russia, so that any instability caused by Islam could affect each republic to some degree.

If we return to our argument regarding Iran's activities in Central Asia, we must emphasize that Iran also has been careful not to put any question marks related with 48-55. 
its religion - Islam and has concentrated more on cultural links with Tajikistan and historical links with Azerbaijan ${ }^{34}$.

For Iran, relations with the Central Asian republics is one way of escaping the political isolation which followed its war with Iraq. Central Asia, as argued by Menon and Barkey ${ }^{35}$, is an important opportunity and source of moral support for Iran because it believes it can offer the Central Asian republics a sense of identity (their vision of (slam) and a state organization.

Yet, Iran with all these aims, does not rely solely on the concept of Islam, but offers Central Asia economic and technical assistance and proposes projects in the fields of energy and transportation.

The other power in the region is China whose relationship with the former Soviet republics changed after the collapse of the USSR.

China is regarded as a model for economic reform by some of the Central Asian republics (argued by Karimov in August 1991) because they think that of all the proposed models only China has faced the same problems (loosening of state control and allowing market mechanisms). They can use the main principle of Chinese strategy, namely, encouraging economic but not political initiative ${ }^{36}$.

There are, however, limitations to the further expansion of political relations between China and the Central Asian republics, the main one being the possibility of spreading the rise of nationalism in Central Asia into China's Xinjiang - Uygur autonomous region which would threaten China's territorial integrity.

According to the 1990 national census, there are 17.6 million Muslim in China (out of a total population of 1.04 billion) composed of approximately 8.6 million Hui (Chinese-speaking Muslims who have nothing in common with other Muslim nationalies in China except Islam); 7.2 million Uygur; 1.1 million Kazakhs; and 375.000 Dongxiang; and $375.000 \mathrm{Kyrgyz}^{37}$. There are also Tajik, Uzbek and Tatar populations. (The Muslim population, except for the Hui, maintain linguistic, territorial and historical affinities with their native countries.)

With the establishment of the Central Asian republics, independence movements in Xinjiang have been strengthened, forcing China's government to further restrict Islamic freedom in the border regions (Muslims in China are mostly concentrated in the northern and northwestern regions at the borders of the former Soviet Union, Afghanistan and Pakistan where the vast majority of China's oil, mineral and

Anthony Parsons, "Central Asia...", Occassional Paper, no: 4, p. 7.

Rajan Menon \& Henri J. Barkey, "The transformation of Central Asia", Survival, vol: 34, no: 4, Winter 1992-1993, p. 75.

Marshall Goldman, "China as a model", Current History, vol: 92, no: 573, Oct 1993, p. 320.

Gerard A. Postiglione, "China's National minority" Journal of Contemporary Asia, vol: 32, no: 1, 1992. 
nuclear power resources are found). China's fears about its teritorial integrity also increased with the meeting of delegates from the Central Asian republics in Kyrgyzstan (July 1992) for the creation of a Free Uygurstan' Party that aims to create a Uygur state in Xinjiang ${ }^{38}$.

Unless there is a fundamental crisis in China's internal and international position, however, ties between the ex-Soviet republics and China could remain relatively stable in the coming years. since neither side has any intention of altering existing relations and creating another area of instability.

Pakistan, being a member of ECO, also tries to establish political and economic ties with the Central Asian republics. This relationship, based on cultural and religious affinities between the Central Asian republics and Pakistan, is not welcomed in India, since India does not want to see a new Pakistan supported by Central Asian states on some issues (e.g. the dispute over Kashmir) which could harm its interests in the region. Thus, the main objective of India in Central Asia is to prevent the creation of a pro-Pakistani coalition of Central Asian republics ${ }^{3}$.

Some Central Asian republics, which think they can repeat the economic miracles experienced in some East Asian countries, like South Korea, Japan and Singapore, see these countries as a model for their future economic development.

Proponents of this idea also argue that Central Asian republics have more natural and human resources than those countries, which could make the chances of economic success even better. The speed with which the economic miracle has accured has made these countries an even more attractive model for Central Asian republics ${ }^{40}$.

The other reason for having Korea as a model is the existence of a significant Korean population (who were deported to Central Asia from the Far East in Stalin's era.) in Kazakhstan, Krygzstan and Uzbekistan.

The main reason is however, that both South Korea and Singapore are capitalist countries which achieved their economic development under strict governmental controls and this feature especially makes them attractive models for officials of the Central Asian republics who want to introduce market economy under politically controlled conditions.

Israel also has been very keen to establish diplomatic and economic relations with the Central Asian republics and has already offered assistance for the construction of irrigation systems in Central Asia and Uzbekistan which has a Jewish minority within its territory has been the first republic to receive help from Israel.

Rajan Menon \& Henri J. Barkey, "The transformation of Central Asia", Survival, vol: 34, no: 4, Winter 92-93, p. 81. Ibid, p. 82.

Bess Brown, "Central Asia and the East Asian model", Report on the USSR, vol: 3, no: 6, February 8,1991 , pp. 9-12. 


\section{CONCLUSION}

Having evaluated Turkey's relations with Central Asian republics and the activities of the neighbouring countries, now it is possible to draw some conclusions concerning Turkey's policies vis-a-vis Central Asian republics.

First of all, these policies are the realistic products of the environmental analyses and are designed to convert the main core of instability triangle (composed of Balkans, the Middle East and the Central Asian republics) into a relatively stable order, eliminating the sources of instability caused by radical ideologies in the region and contributing to creation of a proper environment for the ongoing transformation process by taking into consideration the expectations of Russia. While building up close links with Central Asian republics, Turkey is aiming to achieve a strategic partnership with Russia both at the political and economic levels.

Secondly, Turkish policies vis-a-vis Central Asian republics can neither be conceived as the sole expression of various decisions originating from a single concept of national interest nor can they be based on vague value judgements or ideological propaganda. Rather, the points explained above are concieved as the main determinants in opening up towards the Central Asian republics. This is the stand, assumed by the political line and academic institutions. So this sense of rationalism, that coincide with the realities of the political environment never creates a contradictory situation to other states' conceptions over certain issues.

Turkey's policies vis-a-vis the Central Asian republics, also, are not the sole product of one-sided demands stemming mainly from Turkish decision-making bodies but are formulated according to the demands coming from these states. These policies therefore place a high priority to the understanding of their main problems. Such mutual understanding established between Turkey and the Central Asian republics can not create a conflict situation with other states' overall orientations in the region.

Turkey also considers that its foreign policy objectives towards the region is limited to the creation of a common base on cultural and economic grounds. Although economic relations between Turkey and Central Asian republics have expanded in all sectors, the role Turkey can play in this region will be enhanced with the support of other western countries like the United States, member states of the European Union and Japan. Joint-ventures between Turkish and foreign corporations have great potentials. The role Turkey can play in this region is naturally limited to its 
financial capability, therefore, cooperation with other countries of the region is very important for Turkey.

To conclude, we can point out that the main goal in Turkey's policies vis-a-vis the Central Asian republics aim to create a proper psychological ground in the region, depending on the efficiency and effectiveness of the implementation of foreign policy patterns and to the smooth conclusion of the differentiation process and avoidance of further distruptions or irregularities within the socio-political and economic orders of the new republics. 